\title{
United Nations Psychology Day 2021 Focused on Post-Pandemic Rebuilding
}

\author{
Priyadharshany Sandanapitchai ${ }^{1}$, Harold Takooshian ${ }^{2 \varpi}$ \\ ${ }^{1}$ Rutgers University, \\ 65 Bergen St, Newark, 07107, United States of America \\ ${ }^{2}$ Fordham University, \\ 113 W. 60th Street, New York, 10023, United States of America \\ $\checkmark$ takoosh@aol.com
}

\begin{abstract}
In the wake of the unprecedented global COVID-19 lockdowns in 2020, the Psychology Coalition at the United Nations (PCUN) managed to continue to pursue its mission, to apply psychological science to global issues at the UN. This two-part report offers a concise overview of (a) recent PCUN activities in 2020-2021, and (b) the PCUN's 14th annual Psychology Day at the UN on April 15, 2021, which focused on "Psychological Contributions to Building Back Better in a Post-Pandemic World."
\end{abstract}

Key words: United Nations, Psychology Day, international, COVID-19, NGOs, PCUN

\section{Introduction}

In 2020, the United Nations was poised to celebrate "UN75," the joyous $75^{\text {th }}$ anniversary of its formation on June 26, 1945 (www.un.org/en/75). But tragedy soon intervened. On March 11, 2020, after weeks of hesitation, the UN's World Health Organization (WHO) declared the novel COVID-19 virus outbreak in Wuhan, China, as a "global pandemic" (McNeil, 2020). Like the UN itself, most institutions world-wide quickly "locked down" and cancelled in-person activities, to try to cope with this mysterious and deadly new menace.

Early in 2020, New York City became the epicenter of this deadly virus in the USA, with hospitals overwhelmed by thousands of patients, and refrigerated trucks nearby to hold the bodies of the deceased. Given this grim backdrop, and the impossibility of in-person meetings, the City's countless institutions and organizations each had to decide whether or not to continue operations by shifting to virtual activities.

\section{Psychology Coalition at the United Nations (PCUN)}

Over a dozen psychology organizations have been working with the United Nations during the past 20 years (Takooshian, 2020). Since 2014, about 25-50 members of the Psychology Coalition at the UN were meeting (usually one Thursday

(C) Sandanapitchai P., Takooshian H., 2021

(c) () This work is licensed under a Creative Commons Attribution 4.0 International License 
each month) at various New York City locations at or near the UN headquarters in Manhattan - at City University of New York, Fordham University, or the Salvation Army. In March of 2020, PCUN officers and members voted to shift to a virtual meeting each month and, if feasible, to take this opportunity to expand this meeting to participants in regions outside New York.

As a result, PCUN had a productive year in 2020-2021, in several ways:

- the virtual PCUN monthly meetings expanded, to include visitors from other cities and even nations;

- PCUN strived to continue its normal activities, such as advocacy statements for diverse UN committees;

- on May 27, 2020, PCUN hosted its first virtual Psychology Day at the UN an historic webinar with 1,271 participants from 104 nations;

- also in May of 2020, a new volume appeared on "Psychology in the global arena," with 16 chapters featuring the work of many PCUN representatives and interns (Congress et al., 2020);

- in December of 2020, PCUN voted to sign an agreement with publisher George Johnson of Information Age Publishing (IAP), to launch a unique new series of books on behavioral science applied to global issues;

- in spring of 2021, after months of planning, many PCUN members participated in a new series of seven global webinars. These webinars brought together experts from many nations (like Philip G. Zimbardo in the USA, Isabelle Kamariza in Rwanda, Anjhula Mya Singh Bais in Malaysia, Irina A. Novikova in Moscow, Allyn Enderlyn in Geneva) to share new information on diverse and timely topics. These topics included the role of NGOs at the UN, the UN International Day of Happiness, food insecurity in Africa, "everyday heroes," human rights and genocide;

- in February of 2021, PCUN adopted a new logo, to include its new and more precise title, as provided by UN officials: "The Psychology Coalition of NGOs having Consultative Status with the UN Economic and Social Council;"

- not least of all, PCUN hosted its $14^{\text {th }}$ Psychology Day at the United Nations on April 15, 2021.

\section{Psychology Day at the UN}

The first Psychology Day at the UN was in 2007 - focused on the theme of psychological responses to disasters. Since 2007, this has become an annual tradition in New York City, with a timely new theme each year (see Table).

These forums have increased in size over the years, drawing over 500 colleagues and students to the UN in April of 2019. Though there is no systematic publication of these lively forums, many are now available on video or in written summaries. This includes the forums on "Reducing health inequities" (Marcotte, 2015), "Global migration crisis" (Marcotte, 2016), "Promoting well-being" (Feher, 2017), "Climate change" (Richa, Idahosa-Erere, 2018), "Gender equ[al]ity,"2 and "Multilateralism" (Sandanapitchai, Takooshian, 2020). ${ }^{3}$

${ }^{1}$ UNPD 2018. http://webtv.un.org/search/11th-annual-psychology-day-at-the-unitednations/5769788009001/?term=psychology\%20day\&sort=date

${ }^{2}$ UNPD 2019. http://webtv.un.org/search/the-time-is-now-psychologicalcontributions-to-global-gender $\% \mathrm{C} 2 \% \mathrm{~A} 0$ equality-12th-annual-psychology-day-at-the-

${ }^{3}$ UNPD 2020. https://www.youtube.com/watch?v=AwZrUpbnZ8c 
Themes of Psychology Day at the United Nations, 2007-2021

\begin{tabular}{|c|c|}
\hline Year & Theme \\
\hline 2021 & Psychological Contributions to Building Back Better in a Post-Pandemic World \\
\hline 2020 & $\begin{array}{l}\text { The Multilateralism We Want: Psychological Contributions to Building Bridges Among and Within } \\
\text { Nations }\end{array}$ \\
\hline 2019 & The Time is Now: Psychological Contributions to Global Gender Equ[al]ity \\
\hline 2018 & From Vulnerability to Resilience: Using Psychology to Address the Global Migration Crisis \\
\hline 2017 & $\begin{array}{l}\text { Promoting Well-Being in the } 21^{\text {st }} \text { Century: Psychological Contributions for Social, Economic } \\
\text { and Environmental Challenges }\end{array}$ \\
\hline 2016 & From Vulnerability to Resilience: Using Psychology to Address the Global Migration Crisis \\
\hline 2015 & $\begin{array}{l}\text { Reducing Health Inequalities Within and Among Countries: Psychology's Contributions to } \\
\text { the United Nation's Post- } 2015 \text { Global Agenda }\end{array}$ \\
\hline 2014 & $\begin{array}{l}\text { Psychology's Contributions to Sustainable Development: Challenges and Solutions for the Global } \\
\text { Agenda }\end{array}$ \\
\hline 2013 & Psychology and Violence in a Global Context: Antecedents, Consequences and Prevention \\
\hline 2012 & Human Rights for Vulnerable People \\
\hline 2011 & The Role of Psychology in Achieving Universal Access to Education \\
\hline 2010 & Psychology and Diplomacy: Negotiating for Peace and Human Rights \\
\hline 2009 & No Psychology Day \\
\hline 2008 & Psychology and Social Justice Related to the UN Global \\
\hline 2007 & Psychology and Disaster Response \\
\hline
\end{tabular}

On April 15, 2021, the fourteenth annual Psychology Day at the United Nations drew 1,941 registrants from 97 nations, and over 750 of these participated, on the theme of "Psychological contributions to building back better in a post-pandemic world." In the wake of a year of COVID-19 traumata, this forum engaged five experts in four nations to address five specialties in psychology that can aid in recovery. ${ }^{4}$

This 130-minute webinar was in three parts: (a) it began with introductions by several experts: PCUN President Leslie Popoff, Comfort Asanbe, Janet A. Sigal, Walter Reichman, and Minister Sully Saneaux of the Dominican Republic; (b) five experts spoke on their work for 15 minutes each; (c) this was followed by 25 minutes of question-and-answer with the speakers.

This series of five experts were introduced by H.E. Ambassador Richard Arbeiter of the Permanent Mission of Canada to the United Nations (Figure).

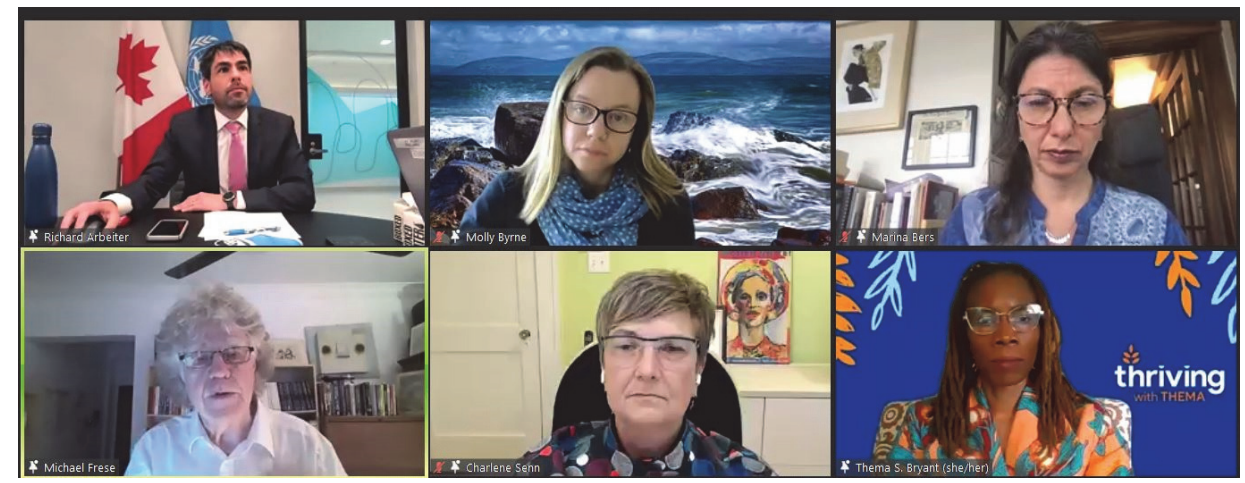

Figure. Moderator Richard Arbeiter with the five experts, Drs. Molly Byrne (Ireland), Marina Umaschi Bers (USA), Michael Frese (Malaysia), Charlene Y. Senn (Canada), Thema Bryant-Davis (USA) (photo from personal archive of authors)

${ }^{4}$ UNPD 2021. https://www.youtube.com/watch?v=z9xR-99IvEs\&t=1329s 
1. Educational psychology. Marina Umaschi Bers, PhD, is Professor and Chair of the Eliot-Pearson Department of Child Study and Human Development at Tufts University. She spoke about "Playground and Playpens: The Role of New Technologies in Learning." The COVID-19 pandemic has made a huge impact on the learning experience of children due to the sudden shift towards virtual platforms causing difficulties for children, teachers and parents to navigate these platforms. However, Dr. Bers' work at DevTech research group is more timely than ever as it aims to explore how technologies can enhance the learning experience and influence positive child development based on pedagogical approaches. By teaching programming languages at an early age, children are engaged in Positive Technological Development (PTD) that promotes communication, collaboration, community building, content creation, creativity and choice of conduct. The Coding as Another Language (CAL) approach, developed by Professor Bers, seeks to examine how learning programming languages can replicate the educational process for teaching literacy. She further clarified that the ultimate goal of learning coding/computer science is not to make every child to become a program developer, but to support young children to develop critical thinking, problemsolving strategies and collaborative skills to become better global citizens.

2. Social psychology. Charlene Y. Senn, PhD, is Professor of Psychology and Gender Studies at the University of Windsor. Dr. Senn addressed "Empowering young women to resist: An evidence-based intervention to reduce sexual violence." Sexual assault is a distinctly gendered crime because the majority of victims are women regardless of age and sexual identity and most perpetrators are men. Although many interventions have been implemented in addressing sexual violence in the past decade, statistics of sexual violence cases have not reduced significantly. Therefore, she emphasized the need of a comprehensive plan for sexual violence prevention and the critical role of psychological science to analyze the effectiveness of such interventions. From a social psychological perspective, she discussed the consequences of cultural messages about the risk of sexual violence around public environment and stranger risk, and how this perpetuates more harm. The EAAA (Enhanced Access, Acknowledge, Act) sexual assault resistance program, founded by Dr. Senn, is a 12 hour, small-group evidence-based intervention. Its goal is to reduce the likelihood that young women experience sexual attack, by decreasing the time to identify the risk cues, reducing the emotional obstacles to take action, and maximizing the chance to use verbal and physical selfdefense tactics. She pointed out that the program has shown promising outcome in reducing the risk of victimization that ensure its future adoption for different languages and cultural settings.

3. Industrial-organizational psychology. Michael Frese, PhD, is Professor of Management at Asia School of Business (Malaysia). He focused on "How work and organizational psychology can contribute to reduce poverty in developing countries." COVID-19 has exacerbated existing inequities and poverty, especially in developing countries. Poverty should not only be viewed from an economic perspective, but also a psychological perspective, to understand the causes and maintenance of poverty. He also acknowledged the role of societal, political, historical and environmental factors on poverty reduction. He identified three areas where psychology is connected to economic development: (a) working hard 
(effort, persistence, achievement motivation); (b) enterprising and innovating (risk taking, autonomy, long term orientation); (c) efficient organizing (trust, leadership, ethical behaviors, team player). Numerous studies have shown that improvement in these three areas is positively associated with higher entrepreneurial success and employee performance. He specifically highlighted the impact of personal initiative - self-starting, future-oriented and proactive mindset - on business performance. His study conducted in Togo, has shown that compared to a traditional business training model, psychological training based on personal initiative had positive effects on micro-entrepreneurs from boosting profits and increasing invention of new products, to motivating them to expand their investments. This is mainly because personal initiative provides tools to tackle challenges, be innovative and unique, and foster better long-term planning for continuous business growth.

4. Clinical psychology. Thema Bryant-Davis, PhD, is a licensed psychologist, ordained minister, artist, and Professor of Psychology at Pepperdine University, where she heads Pepperdine's Culture and Trauma Research Laboratory. She presented on "Thriving in a post-pandemic world: Clinical implications." She started her presentation by acknowledging her identity as an African-descendent woman, since she believes that our identity influences our research, shapes the questions we ask, and the ways we interpret data. The COVID-19 pandemic has caused severe acute and chronic mental health problems. Thus, she stressed the importance of psychological components of recovery and resilience to build back better. Moreover, the pandemic has disproportionately affected specific population like children, individuals with preexisting health conditions, health care workers, immigrants, and racially marginalized groups. Since race-based stress and trauma from police brutality, and racially motivated hate crimes have escalated during the pandemic, it is crucial to address the inequities and injustice as part of treatment considerations. She further explained that treatments should be sensitive to various cultural and spiritual components beside being evidence-based. From a holistic approach, treatments should accommodate various techniques such as mindfulness, self-compassion, healing groups, family and group processing, expressive arts and resistance strategies. Dr. Davis called for "liberation psychology" that not only provides coping tools to deal with trauma and oppression, but also teaches us to resist and dismantle such acts. She concluded by providing key takeaways for thriving in a post-pandemic world: address trauma and loss, rebuild community, engage holistic therapies, integrate expressive arts, and dismantle inequities and injustice.

5. Health psychology. Molly Byrne, PhD, is Professor of Health Psychology in the School of Psychology at National University of Ireland (NUI) in Galway, and Director of its Health Behaviour Change Research Group. She focused on "Contribution from health psychology to building back better in a postpandemic world." Understanding and predicting behaviors have become the center of health psychological research because many of the leading causes of morbidity and mortality are behaviorally determined. In general, health psychologists use psychological science to promote health, prevent illness and improve health care systems. She mentioned, however, health psychology has evolved during this pandemic, since there is now more focus on translating psychological evidence for 
policy and practice. She provided examples of how health psychologists work closely with policymakers to inform global pandemic responses, by providing recommendations and best practices to COVID-19. For example, an international team of health psychologists released a guideline on addressing pandemic fatigue, suggesting four key strategies for government to maintain and reinvigorate public support for protective behaviors: (a) understand people; (b) engage people as part of the solution; (c) allow people to live their lives but reduce risk; (d) acknowledge and address hardship experienced by the people. She indicated that psychologists have an immense role in pandemic preparedness based on numerous evidence-based psychological interventions to deal with global health challenges. She concluded by saying that more funding is needed for psychological and social research relative to biomedical research and international collaboration is the key for an effective pandemic response.

This 2021 Psychology Day program was organized by the sedulous PCUN Program Committee. ${ }^{5}$ It was co-sponsored by 11 psychology organizations, and supported by three diplomatic missions to the UN - Palau, Mexico, and Dominican Republic. A 10-page program for this webinar appears at the UN Psychology Day website: https://www.unpsychologyday.com/. Those interested in past or current PCUN activities can check its website, at http://psychologycoalitionun.org/

\section{References}

Congress, E.P., Takooshian, H., \& Asper, A. (2020). Behavioral science in the global arena. Vol. 1: Addressing timely issues at the UN and beyond. Information Age Publishing. www.infoagepub.com/products/Behavioral-Science-in-the-Global-Arena

Richa, R., \& Idahosa-Erere, E. (2018, Summer). Psychology Day at the United Nations: Climate change mitigation and adaptation. International Psychology Bulletin, 22(3), 21-23.

Feher, Z.M. (2017, Summer). Tenth Psychology Day at the United Nations. International Psychology Bulletin, 21(3), 73-77.

Marcotte, D.P. (2015, Summer). Psychology Day 2015 convened in the United Nations. International Psychology Bulletin, 19(3), 22-23.

Marcotte, D.P. (2016, Summer). Psychology at the United Nations: Focus on the global migration crisis. International Psychology Bulletin, 20(3), 60-61.

McNeil, D.G. (2020, March 11). Coronavirus has become a pandemic, WHO says. The New York Times. https://www.nytimes.com/2020/03/11/health/coronavirus-pandemic-who.html

Sandanapitchai, P., \& Takooshian, H. (2020). United Nations Psychology Day 2020 focused on Multilateralism. RUDN Journal of Psychology and Pedagogics, 17(4), 764-769. http://dx.doi.org/10.22363/2313-1683-2020-17-4-764-769

Takooshian, H., (2020). Psychological science at the United Nations: Historical trends. RUDN Journal of Psychology and Pedagogics, 17(1), 209-213. http://dx.doi.org/10.22363/23131683-2020-17-1-209-213

${ }^{5}$ PCUN Program Committee: Walter Reichman, Janet Sigal, Comfort Asanbe (the three cochairs), and Michelle Bell, Adam Calderone, Roseanne Flores, Ayorkor Gaba, Cynthia Grguric, Rashmi Jaipal, Josephine Juanamarga, Elizabeth Kloner, Judy Kuriansky, Efrat Neter, Nelida Quintero, Odetta Saul, Anna Stauber, and Carmen Vazquez. 
Article history:

Received: 22 April 2021

Revised: 5 May 2021

Accepted: 10 May 2021

\title{
For citation:
}

Sandanapitchai, P., \& Takooshian, H. (2021). United Nations Psychology Day 2021 focused on post-pandemic rebuilding. RUDN Journal of Psychology and Pedagogics, 18(2), 445-452. http://dx.doi.org/10.22363/2313-1683-2021-18-2-445-452

\section{Bio notes:}

Priyadharshany Sandanapitchai, MA, is a research associate at Rutgers University (Newark, USA), serving as an intern with the Society for the Psychological Study of Social Issues at the United Nations. E-mail: priyasandu15@gmail.com

Harold Takooshian, $\mathrm{PhD}$, is Professor of Psychology at Fordham University (New York, USA), representing IMCES (the Institute for Multicultural Counseling and Education Services) at the United Nations. E-mail: takoosh@aol.com

DOI 10.22363/2313-1683-2021-18-2-445-452

Научное сообщение

\section{День психологии - 2021 в ООН, посвященный постпандемическому восстановлению}

\author{
П. Санданапитчай ${ }^{1}$, Г. Такушьян ${ }^{2 凶}$ \\ ${ }^{1}$ Университет Рутгерса, \\ Соединенные Штаты Америки, 07107, Ньюарк, ул. Берген, д. 65 \\ ${ }^{2}$ Университет Фордхэм, \\ Соединенные Штаты Америки, 10023, Нью-Йорк, 60-я ул., д. 113 \\ $\square$ takoosh@aol.com
}

Аннотация. После начала беспрецедентного глобального локдауна, связанного с пандемией COVID-19 в 2020 году, Коалиция психологов в Организации Объединенных Наций (Psychology Coalition at the United Nations, PCUN) смогла продолжить выполнять свою миссию - использовать достижения психологической науки в решении глобальных проблем, обсуждаемых в ООН. В данном научном репортаже, состоящем из двух частей, представлен краткий обзор: 1) недавних мероприятий PCUN в 2020-2021 гг;; 2) 14-го Ежегодного Дня психологии в ООН, организованного 15 апреля 2021 г. при поддержке PCUN и посвященного теме «Вклад психологии в улучшение восстановления в постпандемическом мире».

Ключевые слова: Организация Объединенных Наций, День психологии, международный, COVID-19, неправительственные организации, Коалиция психологов ООН

\section{История статьи:}

Поступила в редакцию: 22 апреля 2021 г.

Принята к печати: 10 мая 2021 г. 


\section{Для цитирования:}

Sandanapitchai P., Takooshian H. United Nations Psychology Day 2021 focused on postpandemic rebuilding // Вестник Российского университета дружбы народов. Серия: Психология и педагогика. 2021. Т. 18. № 2. С. 445-452. http://dx.doi.org/10.22363/23131683-2021-18-2-445-452

\section{Сведения об авторах:}

Санданапитчай Приядхаршани, МА, научный сотрудник университета Рутгерса (Ньюарк, США), интерн Общества психологических исследований социальных вопросов при ООН. E-mail: priyasandu15@gmail.com

Такушьян Гарольд, $\mathrm{PhD}$, профессор психологии в Университете Фордхэм (США, Нью-Йорк). Представитель Института мультикультурного консультирования и образовательных услуг (IMCES) в OOH. E-mail: takoosh@aol.com 